\title{
Cell Wall Metabolism and Induction of Ripening Capacity in 'La France' Pear as Influenced by 2,4-DP
}

\author{
Satoru Kondo ${ }^{1}$ and Yusuke Takano \\ School of Bioresources, Hiroshima Prefectural, University, Shobara, Hiroshima 727-0023, Japan
}

\begin{abstract}
AdDitional INDEX WORDs. auxin, polyuronide, ethylene, Pyrus communis
Abstract. Effects of the synthetic auxin 2,4-DP on fruit ripening of 'La France' pear (Pyrus communis $L$.) on 'Quince C' (Cydonia oblonga Mill. rootstock) were investigated. A solution of $2,4-\mathrm{DP}$ at $90 \mu \mathrm{L} \cdot \mathrm{L}^{-1}$ was applied 143, 151, and 159 days after full bloom (DAFB) to whole trees and compared with nonstored nontreated fruit and stored nontreated fruit (harvested 165 DAFB). Internal ethylene concentration in 2,4-DP-treated fruit increased more than in nonstored nontreated fruit and the level was higher the earlier the application time. Fruit firmness decreased earliest for fruit treated with 2,4-DP at 143 DAFB, followed by 151 DAFB-treated fruit and then 159 DAFB-treated fruit. In the nonstored nontreated fruit, firmness also showed a slight decrease with time. In all 2,4-DP treatments, water-soluble polyuronide (WSP) increased with ripening and hexametaphosphate-soluble polyuronide (HMP) and HCl-soluble polyuronide (HP) concentrations decreased. Most notably, WSP concentration increased earliest in fruit treated with 2,4-DP at 143 DAFB. Total concentration of neutral sugars from cell walls in each treatment decreased with time, and the levels in fruit treated with 2,4-DP at 143 DAFB were lowest at each sampling time. Arabinose concentrations were high compared with other neutral sugars throughout fruit ripening for each treatment, while glucose concentrations were high in nonripened fruit. At 193 DAFB, $\approx 85 \%$ of the fruit treated with 2,4-DP at 143 DAFB reached edible condition (firmness not more than 0.4 $\mathrm{N} \cdot \mathrm{mm}^{-2}$ ) on the tree. Furthermore, $\approx 85 \%$ of the fruit treated with $2,4-\mathrm{DP}$ at 151 DAFB reached edible condition on 200 DAFB and close to $100 \%$ of the fruit treated with 2,4-DP at 159 DAFB on 207 DAFB. When ripened in a controlled room at $20{ }^{\circ} \mathrm{C}$ and $90 \%$ relative humidity after 2,4-DP treatment, the fruit treated earliest reached edible condition the soonest. Results demonstrate that 2,4-DP treatment can be used as an effective method of producing good quality fruit ripened on the tree, and that 2,4-DP may be an adequate replacement for cold storage conditioning to induce ripening capacity. Chemical name used: 2,4-dichlorophenoxy-propionic acid (2,4-DP).
\end{abstract}

Pears (Pyrus communis) that ripen in storage eventually develop into juicy fruit with buttery texture. The harvest date of some early cultivars such as 'Bartlett' can be determined by a change in skin color (Wang et al., 1971). However, most cultivars, including 'La France', show no significant change in skin color while on the tree. Therefore, harvest date must be determined by other methods such as days after full bloom (DAFB) or changes in fruit firmness (Satoh, 1996). The rate of fruit ripening varies among years making it more difficult to determine the optimum harvest date. Harvesting too early or too late decreases some fruit quality characteristics such as flavor (Chen and Mellenthin, 1981). Fruit quality is related to its cell wall metabolism, and fruit lacking juicy and buttery texture have a lower concentration of water-soluble polyuronide (WSP) (Murayama et al., 1998). Furthermore, cell wall metabolism is related to ethylene production from fruit and WSP concentration increases with a corresponding increase in ethylene production (Gerasopoulos and Richardson, 1997).

When pears are ripened at room temperature after harvest, individual fruit ripen at different rates (Satoh, 1996). However, after cold storage, when the fruit is returned to a warmer temperature, ethylene production is stimulated and ripening proceeds at a more uniform rate (Blankenship and Richardson, 1985). Therefore, 'La France' pears are ripened generally in cold storage at 5 ${ }^{\circ} \mathrm{C}$ for $10 \mathrm{~d}$. After harvest, if ethylene treatment is used in place of cold storage, good fruit quality cannot always be achieved (Knee, 1993). This may be because fruit softening is promoted

Received for publication 8 Feb. 1999. Accepted for publication 13 Nov. 1999. We thank Takaaki Manabe for comments regarding this manuscript. The cost of publishing this paper was defrayed in part by the payment of page charges. Under postal regulations, this paper therefore must be hereby marked advertisement solely to indicate this fact.

${ }^{1}$ To whom reprint requests should be addressed. E-mail: s-kondo@ bio.hiroshimapu.ac.jp. too rapidly. We have reported previously that use of the synthetic auxin 2,4-DP, which is used in Japan on apples [Malus sylvestris (L.) Mill. var. domestica (Borkh.) Mansf.] as a retardant against preharvest fruit drop, also promotes ethylene production and therefore can promote fruit ripening, i.e., the promotion of change in fruit pigmentation and a decrease in fruit firmness (Kondo and Hayata, 1995). If pears can be ripened with good quality on the tree without using cold storage, then the fruit may be marketed more effectively. In this study the effect of different 2,4-DP concentrations and application times on pear ripening was investigated by measuring fruit firmness, coloration, internal ethylene concentration (IEC), and cell wall metabolism.

\section{Materials and Methods}

Forty randomly selected 9 to 10 -year-old 'La France' pear trees grafted onto 'Quince C' (Cydonia oblonga) rootstock growing in an open field at Hiroshima Prefectural University were used in 1997 and 1998. Similar experiments were performed in 1997 and 1998, but the dates used in each year varied. Since results from both years were similar but the dates do not correlate well, only the 1998 results were used for this report. Eight test groups of five trees each were created. Treatments to each group are described in Table 1. From each of the first seven groups, 15 fruit were labeled and fruit diameter was measured every $10 \mathrm{~d}$ from 143 to 207 DAFB. In groups two to seven, two concentrations of 2,4-DP ( 45 or $\left.90 \mu \mathrm{L} \cdot \mathrm{L}^{-1}\right)$ were applied early (143 DAFB), middle (151 DAFB), or late (159 DAFB). Eight fruit from each tree in the group (40 fruit) were sampled every $7 \mathrm{~d}$ from 165 to 207 DAFB. In order to determine on-the-tree changes, half of these fruit were analyzed immediately for fruit firmness, sugar concentration, IEC, polyuronide concentration, neutral sugar concentration, and molecular weight of polyuronide. To determine days off the tree to achieve edible condition (firmness $\leq 0.4 \mathrm{~N} \cdot \mathrm{mm}^{-2}$ ), 20 
Table 1. Eight test groups on 'La France' pears.

\begin{tabular}{lcl}
\hline \hline Treatment & $2,4-\mathrm{DP}\left(\mu \mathrm{L} \cdot \mathrm{L}^{-1}\right)$ & Treatment description \\
\hline 1) Nonstored nontreated & 0 & Nontreated with 2,4-DP \\
2) Early & 45 & Treated with 2,4-DP at 143 DAFB \\
3) & 90 & \\
4) Middle & 45 & Treated with 2,4-DP at 151 DAFB \\
5) & 90 & Treated with 2,4-DP at 159 DAFB \\
6) Late & 45 & \\
7) & 90 & Nontreated fruit harvested at 165 DAFB and stored \\
8) Stored nontreated & 0 &
\end{tabular}

${ }^{\mathrm{z}} \mathrm{DAFB}=$ days after full bloom.

fruit of groups one to seven were placed immediately in a controlled room at $20^{\circ} \mathrm{C}$ and $90 \%$ relative humidity $(\mathrm{RH})$, then examined every $2 \mathrm{~d}$ for ripened fruit firmness. From the eighth test group (stored nontreated), 120 fruit from the nontreated trees were harvested on the optimum harvest date for 'La France' pear trees (165 DAFB) and placed in a controlled room at $20^{\circ} \mathrm{C}$ and $90 \% \mathrm{RH}$ for $35 \mathrm{~d}$. From this group, 20 fruit were removed from storage every $7 \mathrm{~d}$ and analyzed for fruit firmness, sugar concentration, IEC, polyuronide concentration, neutral sugar concentration, and molecular weight of polyuronide.

Fruit Firmness, hue VALUE, IEC, AND SUGAR CONCENTRATION. The color of 10 fruit from each sample group was analyzed using a chromameter (CR-200; Minolta Co., Ltd. Osaka, Japan). Measurements were taken on two shaded fruit surfaces at the equator of each fruit and hue values were determined by the method of McGuire (1992). After fruit color was measured, fruit firmness was determined with a rheometer (NRM-2002J; Fudo Ind. Co., Tokyo; needle diameter $=1 \mathrm{~mm}$ ) on the fruit equator after the skin had been removed with a knife. IEC was measured immediately after sampling. Five fruit from each sample group were sampled for IEC by removing a $1-\mathrm{mL}$ air sample from the core of the fruit with a syringe and injecting it into a gas chromatograph (GC-380; GL Sciences, Inc., Tokyo; column = Porapak Q, i.d. $2.2 \mathrm{~mm} \times 2.0$ $\mathrm{m})$.

After the pulp samples were heated to devitalize invertase activity for $30 \mathrm{~s}$ using a microwave oven, samples were extracted with $13.7 \mathrm{~mol} \cdot \mathrm{L}^{-1}(80 \%)$ ethanol and the solvent was evaporated in a vacuum to the aqueous phase. The sugar concentration was determined quantitatively by high pressure liquid chromatography (HPLC) [Gulliver series; Japan Spectroscopic Co., Tokyo; column $=$ Shodex $($ Showa Denko Co., Tokyo $), 4.6 \mathrm{~mm}$ i.d. $\times 30$ $\mathrm{cm}$; column temperature $=60^{\circ} \mathrm{C}$; mobile phase $=$ distilled water; flow rate $=1.0 \mathrm{~mL} \cdot \mathrm{min}^{-1}$; detector $=$ refractive index $]$.

Polyuronide, neutral Sugar Concentration, AND MOlecuLAR WEIGHT. Fifteen fruit from each sample group (three replications of five fruit ) were used for analysis of polyuronide and neutral sugar concentrations. After pulp tissue was heated in 13.7 $\mathrm{mol} \cdot \mathrm{L}^{-1}$ ethanol at $70{ }^{\circ} \mathrm{C}$ for $30 \mathrm{~min}$, it was then homogenated in ethanol adjusted to maintain $13.7 \mathrm{~mol} \cdot \mathrm{L}^{-1}$. After the homogenate was passed through a glass filter, the residue was washed repeatedly with $13.7 \mathrm{~mol} \cdot \mathrm{L}^{-1}$ ethanol until nondetection of sugars, followed by $17.1 \mathrm{~mol} \cdot \mathrm{L}^{-1}(100 \%)$ ethanol, $13.6 \mathrm{~mol} \cdot \mathrm{L}^{-1}(100 \%)$ acetone, and $9.6 \mathrm{~mol} \cdot \mathrm{L}^{-1}(100 \%)$ diethyl ether to obtain the alcohol-insoluble solids (AIS). After diethyl ether was removed, AIS were dried at $<40^{\circ} \mathrm{C}$ in a vacuum oven and then placed in a desiccator over phosphorus pentoxide for at least $24 \mathrm{~h}$ and powdered. One hundred milligrams AIS was suspended in $50 \mathrm{~mL}$ distilled water, shaken overnight, and filtered.

The filtrate was used for water-soluble polyuronide (WSP) determination. The residue was resuspended at $90{ }^{\circ} \mathrm{C}$ for $1 \mathrm{~h}$ in a $50-\mathrm{mL}$ solution of $0.4 \%(\mathrm{w} / \mathrm{v})$ sodium hexametaphosphate and after filtration, the filtrate was used for hexametaphosphatesoluble polyuronide (HMP) determination. The residue was then resuspended for $1 \mathrm{~h}$ in $50 \mathrm{~mL} 50-\mathrm{mmol} \cdot \mathrm{L}^{-1} \mathrm{HCl}$ at $90{ }^{\circ} \mathrm{C}$ and the solution was filtered with the filtrate used for $\mathrm{HCl}$-soluble polyuronide (HP) determination. The polyuronide concentration in each fraction was expressed as the galacturonic acid concentration using the 3,5-dimethyl phenol method (Manabe, 1993).

Neutral sugars in AIS were derivatized to alditol acetates by hydrolysis with $2 \mathrm{~mol} \cdot \mathrm{L}^{-1}$ trifluoroacetic acid (TFA), with reduction and acetylation according to the method of Albersheim et al. (1967). The derivatives were separated and identified by gas chromatography, with a flame ionization detector (GL-380; GL Sciences, Inc., Tokyo) using a DB-225 column (J\&W Scientific, Folsom, Calif.; $0.25 \mathrm{~mm}$ i.d. $\times 30 \mathrm{~m}$ ) with a column temperature of $210{ }^{\circ} \mathrm{C}$.

The average molecular weight of polyuronides in WSP, HMP, and HP fractions were measured using HPLC (Gulliver series; Japan Spectroscopic Co.; column (two columns of same length were connected in series) $=$ TSKgel GMPW $(\mathrm{XL})$ and TSKgel $\mathrm{G} 3000 \mathrm{PW} \mathrm{XL}_{(\mathrm{L})}($ Tosoh Co., Tokyo), $7.5 \mathrm{~mm}$ i.d. $\times 30 \mathrm{~cm}$; column temperature $=30^{\circ} \mathrm{C}$; mobile phase $=$ distilled water; flow rate $=$ $0.5 \mathrm{~mL} \cdot \mathrm{min}^{-1}$; detector $=$ refractive index $)$.

Statistical ANALYSIS. Data were subjected to analyses of variance and LSD procedures were used for mean separation (SAS Institute, Inc., Cary, N.C.).

\section{Results}

The $45 \mu \mathrm{L} \cdot \mathrm{L}^{-1}$ 2,4-DP early, middle, and late applications accelerated fruit ripening compared with the nonstored nontreated fruit. However, the difference among application times was unclear and the ripening times of individual fruit had fluctuations at each treatment (data not presented). Data reported herein are from the $90-\mu \mathrm{L} \cdot \mathrm{L}^{-1} 2,4-\mathrm{DP}$ application, which had time to ripen to an edible condition most clearly distinguished for each application time.

Fruit firmness, hUE VAlUe, iec, AND SUgar CONCENTRATion. Fruit firmness decreased most rapidly following 2,4-DP treatment at 143 DAFB (early), followed by 151 DAFB (mid), and 159 DAFB (late) (Fig. 1). Fruit from the three 2,4-DP treatments and stored nontreated fruit ripened to an edible firmness of not more than $0.4 \mathrm{~N} \cdot \mathrm{mm}^{-2}$. In the nonstored nontreated fruit, firmness also decreased slightly with time reaching $0.8 \mathrm{~N} \cdot \mathrm{mm}^{-2}$ on $207 \mathrm{DAFB}$, but the fruit did not reach edible condition $\left(0.4 \mathrm{~N} \cdot \mathrm{mm}^{-2}\right)$. In the 2,4-DP treatments, the skin color changed gradually from green to yellow (Fig. 2). The change was most rapid in early-treated fruit, followed by mid and then late. Almost no changes in color 


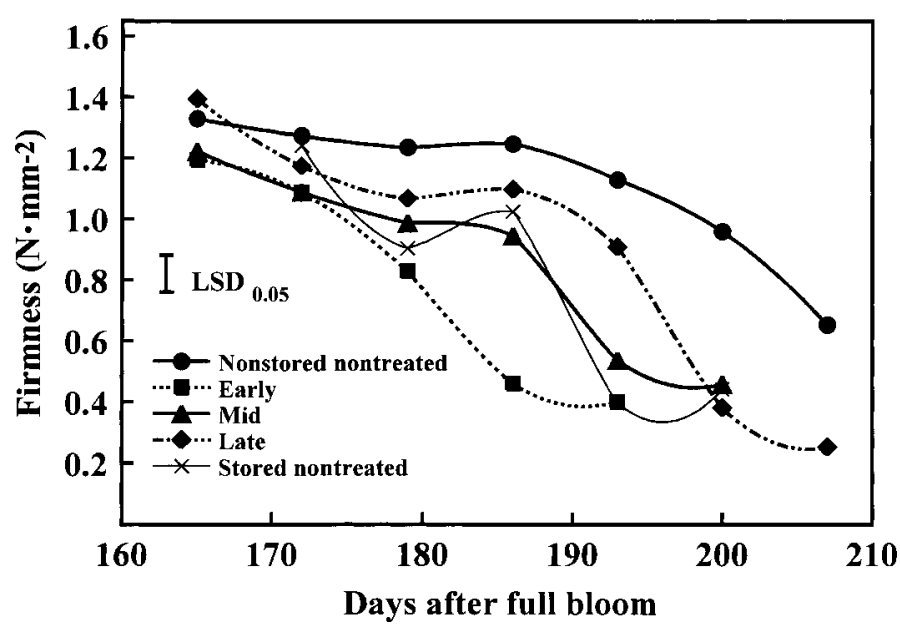

Fig. 1. Firmness of pears on the tree (nontreated, early, middle, and late $90-\mu \mathrm{L} \cdot \mathrm{L}^{-1}$ 2,4-DP treatments) and stored nontreated fruit harvested at 165 DAFB (stored nontreated treatment). See Table 1 for legend details. The $90-\mu \mathrm{L} \cdot \mathrm{L}^{-1} 2,4-\mathrm{DP}$ solution was applied to whole trees. Each symbol is the mean of 10 fruit.

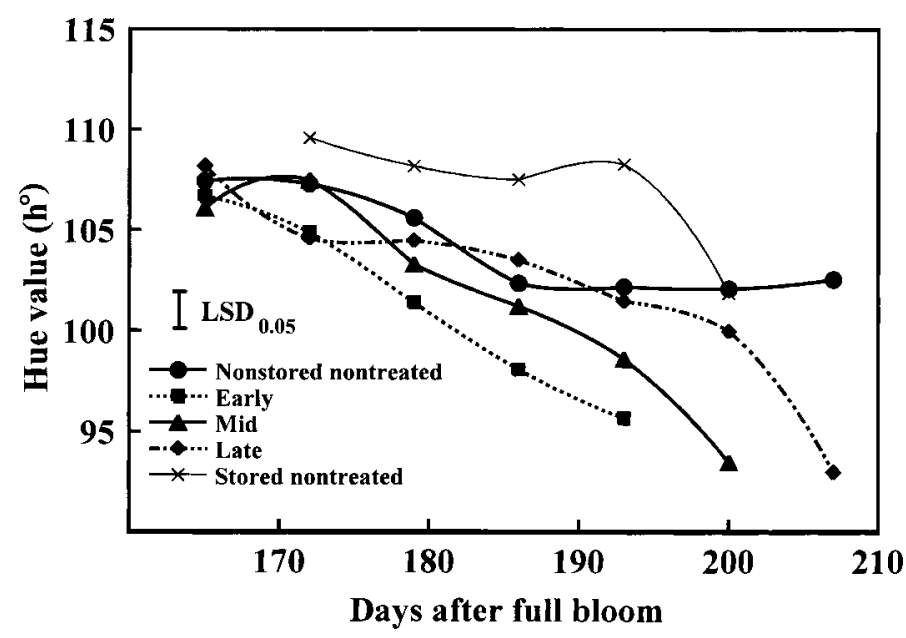

Fig. 2. Changes in ground color (hue value) of pears on the tree (nontreated, early, middle, and late $90-\mu \mathrm{L} \cdot \mathrm{L}^{-1} 2,4-\mathrm{DP}$ treatments) and stored nontreated fruit harvested at 165 DAFB (stored nontreated treatment). See Table 1 for legend details. The $90-\mu \mathrm{L} \cdot \mathrm{L}^{-1} 2,4-$ DP solution was applied to whole trees. Each symbol is the mean of 10 fruit. Hue value $\left(0^{\circ}=\right.$ red-purple, $90^{\circ}=$ yellow, $180^{\circ}=$ bluish-green, $270^{\circ}=$ blue $)$ was calculated according to McGuire (1992).

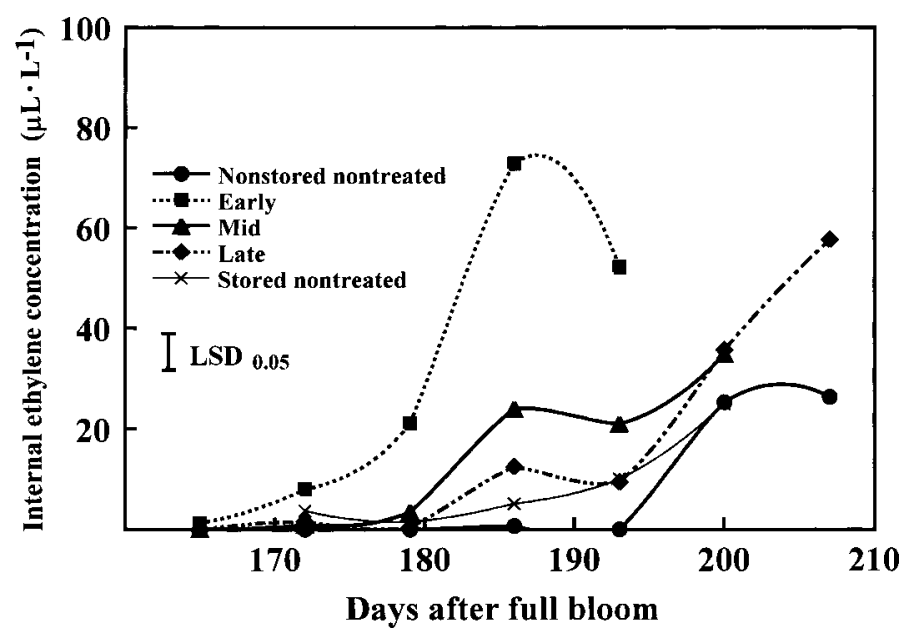

Fig. 3. Internal ethylene concentrations of pears on the tree (nontreated, early, middle, and late $90-\mu \mathrm{L} \cdot \mathrm{L}^{-1} 2,4-\mathrm{DP}$ treatments) and stored nontreated fruit harvested at $165 \mathrm{DAFB}$ (stored nontreated treatment). See Table 1 for legend details. The $90-\mu \mathrm{L} \cdot \mathrm{L}^{-1} 2,4-\mathrm{DP}$ solution was applied to whole trees. Each symbol is the mean of 10 fruit. were observed in nontreated fruit. Although changes in color were not found in stored nontreated fruit until 193 DAFB, it changed slightly towards yellow on 200 DAFB when the fruit had ripened to edible condition. IEC concentrations in 2,4-DP-treated fruit and in stored nontreated fruit increased gradually with time (Fig. 3). Again, the concentrations in early-treated fruit were the highest, followed by mid, late, and lastly stored nontreated fruit. In nonstored nontreated fruit, almost no changes were observed until 193 DAFB after which the levels increased until 200 DAFB.

About $50 \%$ of early-treated fruit ripened to edible condition when harvested after 186 DAFB on the tree, and then $\approx 85 \%$ reached this condition at 193 DAFB (Fig. 4). In mid-treated fruit, $\approx 50 \%$ reached edible condition when harvested after 193 DAFB and $\approx 85 \%$ at 200 DAFB. In late-treated fruit, most fruit reached edible condition at 207 DAFB on the tree. Fruit with later harvest dates and earlier 2,4-DP application dates required shorter periods of time to reach edible condition after being harvested and placed in a controlled room for ripening. For instance, when fruit were harvested 165 DAFB, $16 \mathrm{~d}$ were required by early-treated fruit for all fruit to reach edible condition, $26 \mathrm{~d}$ were required by mid-treated fruit, $36 \mathrm{~d}$ by late-treated fruit, and $34 \mathrm{~d}$ by nonstorerd nontreated fruit. As for the fruit harvested at $186 \mathrm{DAFB}, 9 \mathrm{~d}$ were required by early-treated fruit, $11 \mathrm{~d}$ by mid-treated fruit, $15 \mathrm{~d}$ by late-treated fruit and $21 \mathrm{~d}$ by nonstored nontreated fruit.

Nonstored nontreated fruit and late-treated fruit had slightly larger diameters than early- and mid-treated fruit (Fig. 5). Significant differences in fruit sugar levels (the total of sucrose, glucose, fructose, and sorbitol) were not observed at any time in each treatment (data not presented).

Polyuronide, neutral sugar Concentration, AND MOlecuLAR WEIGHT. In 2,4-DP-treated fruit and the stored nontreated fruit, total polyuronide concentrations decreased sequentially with ripening (Table 2 ). Also, WSP concentrations increased and HMP and HP concentrations decreased gradually. Total polyuronide concentrations at the date when most fruit reached edible condition for each treatment (i.e., early-treated fruit $=193$ DAFB, mid-treated fruit $=200$ DAFB, late-treated fruit $=207$ DAFB, stored nontreated $=35 \mathrm{~d}$ after storage) were 1.7 to 1.9 $\mathrm{mg} \cdot \mathrm{g}^{-1}$ fresh weight $(\mathrm{FW})$ and percentages of WSP were $79 \%$ to $84 \%$. In the nonstored nontreated fruit, a decrease in total polyuronide, an increase of WSP, and a decrease of HMP were observed. However, the levels were slight compared with the other treatments.

Average molecular weight of polyuronide in WSP was around $6 \mathrm{kDa}$, that of HMP was $70 \mathrm{kDa}$, and that of $\mathrm{HP}$ was $25 \mathrm{kDa}$, and these values displayed almost no change throughout ripening (data not presented).

Total concentrations of neutral sugars from cell walls decreased gradually with ripening (Table 3 ). Levels were the lowest in early-treated fruit and the highest in the nonstored nontreated fruit. Arabinose comprised $40 \% \pm 1.7 \%$ ( $\pm \mathrm{SE}$ ) of total neutral sugar concentrations in early-treated fruit, while glucose made up $53 \%$ of neutral sugars in nonstored nontreated fruit at 179 DAFB.

\section{Discussion}

In apple, when ripening is completed on the tree, IEC increases dramatically before harvest and softening and coloration are promoted (Kondo et al., 1991). In this study, IEC from 2,4-DPtreated pears increased significantly and fruit firmness decreased (Figs. 1 and 3). Loss of fruit firmness coincides with an increase in WSP in 'Anjou' pears (Gerasopoulos and Richardson, 1997). 


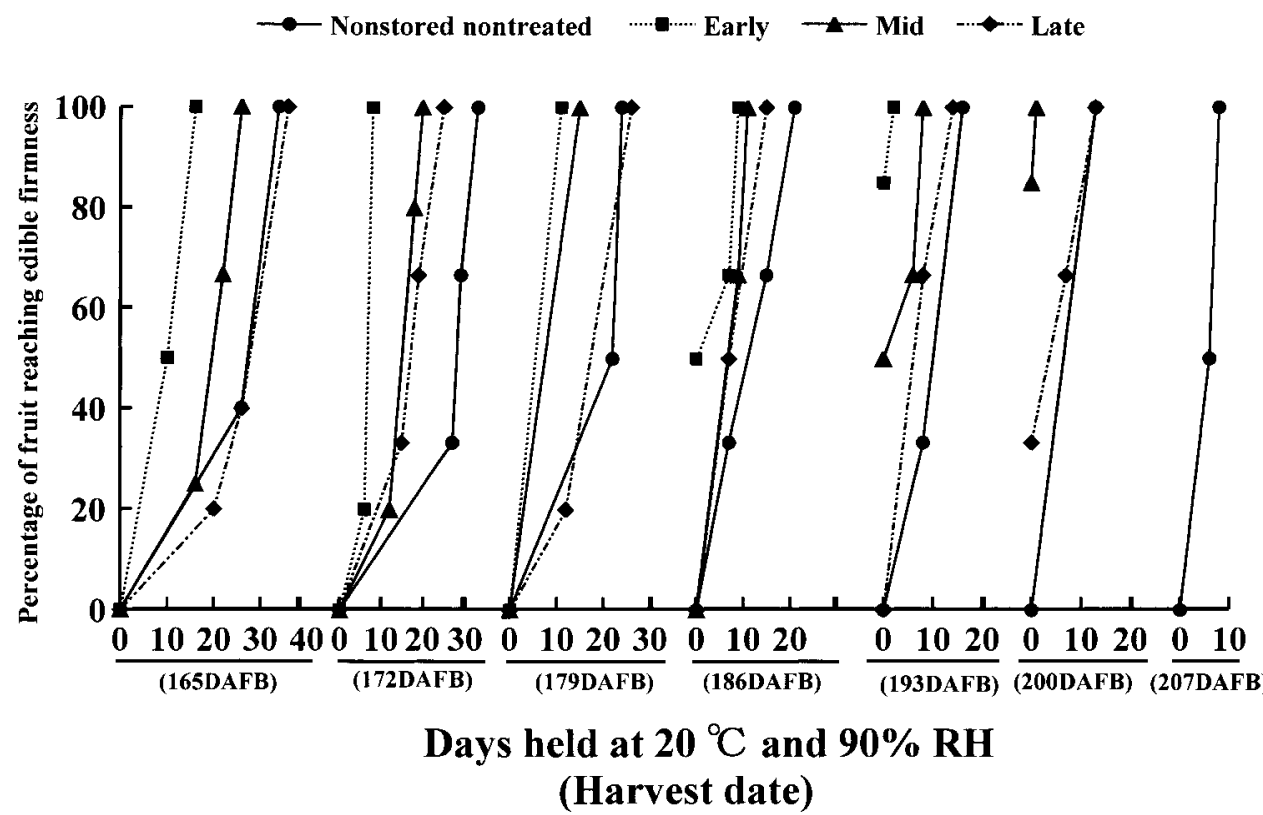

Fig. 4. Days required for fruit to reach edible firmness $\left(\leq 0.4 \mathrm{~N} \cdot \mathrm{mm}^{-2}\right)$ in a $20^{\circ} \mathrm{C}$ and $90 \%$ RH room after early, middle, and late $90-\mu \mathrm{L} \cdot \mathrm{L}^{-1} 2,4-\mathrm{DP}$-treated and nontreated fruit were harvested. See Table 1 for legend details. The $90-\mu \mathrm{L} \cdot \mathrm{L}^{-1} 2,4-\mathrm{DP}$ solution was applied to whole trees. Twenty fruit were used in each treatment.

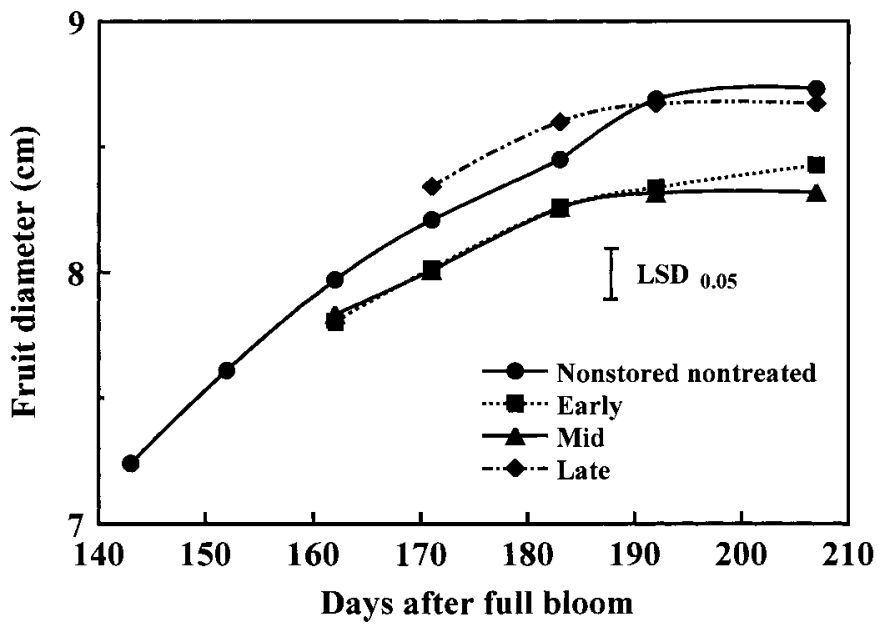

Fig. 5. Fruit diameter changes in early, middle, and late $90-\mu \mathrm{L} \cdot \mathrm{L}^{-1} 2,4-\mathrm{DP}-$ treated and nontreated fruit. See Table 1 for legend details. The $90-\mu \mathrm{L} \cdot \mathrm{L}^{-1} 2,4-\mathrm{DP}$ solution was applied to whole trees. Each symbol is the mean of 15 fruit.

In this study, percentage of WSP in total polyuronides increased more rapidly the earlier the application time of 2,4-DP, the most rapid increase being found in early-treated fruit, which also had the highest ethylene concentration. This suggests the increase of IEC by 2,4-DP application promoted fruit softening. IEC in nonstored nontreated fruit also increased greatly after 193 DAFB and the levels reached almost the same as those of the stored nontreated fruit. Although stored nontreated fruit ripened to edible condition by 200 DAFB, nonstored nontreated fruit did not, i.e., fruit firmness did not decrease and WSP concentration did not show a great increase. Murayama et al. (1998) demonstrated that cell wall synthesis might continue on the tree because pear volume continued to increase substantially until harvest. Inhibition of fruit growth following 2,4-DP treatment while promoting fruit ripening supports this hypothesis. Furthermore, other hormones produced in leaves and roots (i.e., gibberellins and cytokinins) (Nii, 1998), which can inhibit senescence, may be translocated to fruit on the tree until harvest. These results suggest that ripening on the tree is associated with more IEC compared with IEC in stored fruit.

In the nonstored nontreated group fruit drop, which may also be caused by the increase of IEC, increased after 193 DAFB (data not presented). Although ethylene levels in 2,4-DP-treated fruit were higher, compared with nonstored nontreated fruit, fruit drop might not have occurred because the auxin inhibited abscission layer formation as observed previously in apples (Kondo and Hayata, 1995).

Gerasopoulos and Richardson (1997) reported that ACC concentration, ACC oxidase activity, and internal ethylene production in 'Anjou' pear did not increase if fruit were not chilled. Most pear cultivars require a chilling temperature to increase internal ethylene levels on return to a higher temperature to ripen with a buttery and juicy texture (Chen et al., 1983). If fruit is not chilled, uniform ripening of individual fruit is not accomplished (Blankenship and Richardson, 1985). In this study, internal ethylene levels of each 2,4-DP-treated fruit were higher, compared with nonstored nontreated fruit, and the levels were higher for earlier application times. Hence, it can be assumed that an earlier application such as 143 DAFB is effective for ethylene induction by the fruit. Also, pears placed at $20{ }^{\circ} \mathrm{C}$ and $90 \% \mathrm{RH}$ after 2,4-DP application reached edible condition earlier than the nonstored nontreated fruit placed in the same condition, suggesting that 2,4-DP-treated fruit can be marketed without use of cold storage immediately after harvest.

Development of pears with marketable quality and juicy texture is related to the increase of WSP (Chen et al., 1993; Gerasopoulos and Richardson, 1997; Murayama et al., 1998). Results of our study agree with this hypothesis. That is, in nonstored nontreated fruit that did not ripen to edible firmness on the tree, the percentage of WSP in total polyuronides was low. In contrast, 2,4-DP-treated fruit developed buttery and juicy texture and showed an increase in WSP. Since HMP and HP decreased with time, it is possible they were transformed into WSP. In this study, the average molecular weight of the HP fraction was smaller than that of the HMP fraction. Michel et al. (1985) reported that extraction of polyuronide under low $\mathrm{pH}$ and high temperature conditions caused cleavage of polyuronide linkage, resulting in a decrease in molecular weight. Thus, average molecular weight of the HP fraction observed in this study may be smaller when compared with its original value. It has been shown that although the amount of low-molecular-weight polyuronide in WSP increases with ripening in 'Red Bartlett' pears, the amount of EDTA-soluble fractions decreases during ripening without further changes in molecular weight (Yoshioka et al., 1992). The average molecular weight of the fractionated soluble pectins in juice sacs of satsuma mandarin fruit (Citrus unshiu Marc.) were nearly constant during $120 \mathrm{~d}$ storage (Naohara and Manabe, 1994). Also in this study, average molecular weight of polyuronide in WSP, HMP, and HP fractions displayed almost no 


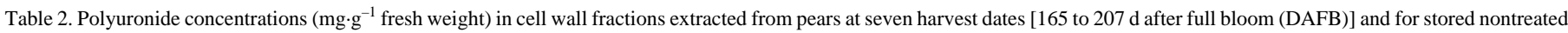
pears (harvested 165 DAFB)

\begin{tabular}{|c|c|c|c|c|c|c|c|c|c|c|c|c|c|c|c|c|c|c|c|c|c|}
\hline \multirow[b]{2}{*}{ DAFB } & \multicolumn{4}{|c|}{$\begin{array}{l}\text { Nonstored } \\
\text { nontreated }^{2}\end{array}$} & \multicolumn{4}{|c|}{$\begin{array}{c}\text { Early } \\
2,4-\mathrm{DP}\end{array}$} & \multicolumn{4}{|c|}{$\begin{array}{l}\text { Middle } \\
2,4-\mathrm{DP}\end{array}$} & \multicolumn{4}{|c|}{$\begin{array}{c}\text { Late } \\
\text { 2,4-DP }\end{array}$} & \multirow{2}{*}{$\begin{array}{l}\text { Storage } \\
\text { time } \\
\text { (d) }\end{array}$} & \multicolumn{4}{|c|}{$\begin{array}{c}\text { Stored } \\
\text { nontreated }\end{array}$} \\
\hline & WSP & HMP & HP & Total & WSP & HMP & HP & Total & WSP & HMP & HP & Total & WSP & HMP & HP & Total & & WSP & HMP & HP & Total \\
\hline 165 & $0.29^{y}$ & 3.07 & 0.17 & 3.53 & 0.93 & 2.50 & 0.07 & 3.50 & 0.34 & 2.68 & 0.13 & 3.15 & 0.29 & 3.91 & 0.20 & 4.40 & & & & & \\
\hline 172 & 0.32 & 3.19 & 0.11 & 3.62 & 0.91 & 1.25 & 0.05 & 2.21 & 0.70 & 2.12 & 0.10 & 2.92 & 0.28 & 2.74 & 0.20 & 3.22 & 7 & 0.50 & 2.39 & 0.13 & 3.02 \\
\hline 179 & 0.42 & 3.10 & 0.07 & 3.59 & 0.99 & 1.00 & 0.05 & 2.04 & 1.06 & 1.35 & 0.09 & 2.50 & 0.56 & 2.87 & 0.15 & 3.58 & 14 & 0.94 & 1.31 & 0.07 & 2.32 \\
\hline 186 & 0.47 & 2.88 & 0.09 & 3.44 & 1.32 & 0.50 & 0.03 & 1.85 & 1.17 & 1.06 & 0.05 & 2.28 & 0.68 & 1.58 & 0.11 & 2.37 & 21 & 1.16 & 0.77 & 0.04 & 1.97 \\
\hline 193 & 0.64 & 2.38 & 0.09 & 3.11 & 1.37 & 0.32 & 0.04 & 1.73 & 1.52 & 0.53 & 0.04 & 2.09 & 1.34 & 0.61 & 0.07 & 2.02 & 28 & 1.55 & 0.46 & 0.04 & 2.05 \\
\hline 200 & 1.07 & 1.98 & 0.08 & 3.13 & & & & & 1.41 & 0.33 & 0.03 & 1.77 & 1.57 & 0.50 & 0.06 & 2.13 & 35 & 1.60 & 0.30 & 0.01 & 1.91 \\
\hline 207 & 1.00 & 1.58 & 0.07 & 2.65 & & & & & & & & & 1.41 & 0.33 & 0.04 & 1.78 & & & & & \\
\hline
\end{tabular}

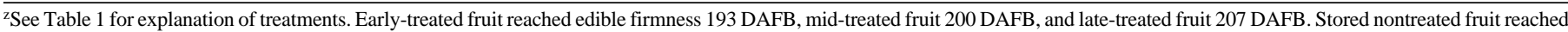
edible firmness after $35 \mathrm{~d}$.

${ }^{y}$ Data are the means (a standard error of each mean is $<7 \%$ ) of three replications.

Table 3. Neutral sugar concentrations $\left[\mathrm{mg} \cdot \mathrm{g}^{-1}\right.$ fresh weight $\left.(\mathrm{FW})\right]$ in cell walls extracted from pears at five harvest [179 to $207 \mathrm{~d}$ after full bloom (DAFB)] and for stored nontreated pears (harvested 165 DAFB).

\begin{tabular}{|c|c|c|c|c|c|c|c|c|c|}
\hline \multirow[b]{2}{*}{ Treatment $^{\mathrm{Z}}$} & \multirow[b]{2}{*}{ DAFB } & \multicolumn{8}{|c|}{ Neutral sugar concn $\left(\mathrm{mg} \cdot \mathrm{g}^{-1} \mathrm{FW}\right)$} \\
\hline & & Rhamnose & Fucose & Arabinose & Xylose & Mannose & Galactose & Glucose & Total \\
\hline Nonstored nontreated & 179 & $0.11^{\mathrm{y}}$ & 0.12 & 3.03 & 1.61 & 0.07 & 1.34 & 7.20 & 13.48 \\
\hline Early & 179 & 0.05 & 0.07 & 2.52 & 0.98 & 0.01 & 0.74 & 1.75 & 6.12 \\
\hline Mid & 179 & 0.09 & 0.11 & 2.54 & 1.57 & 0.01 & 0.99 & 2.17 & 7.48 \\
\hline Late & 179 & 0.11 & 0.12 & 3.10 & 1.52 & 0.01 & 1.21 & 5.02 & 11.09 \\
\hline Stored nontreated & $(14)^{x}$ & 0.13 & 0.15 & 3.94 & 1.59 & 0.01 & 0.96 & 1.28 & 8.06 \\
\hline Nonstored nontreated & 186 & 0.11 & 0.11 & 3.22 & 1.56 & 0.01 & 1.15 & 4.83 & 10.99 \\
\hline Early & 186 & 0.08 & 0.12 & 2.24 & 1.38 & 0.01 & 0.79 & 0.51 & 5.13 \\
\hline Mid & 186 & 0.08 & 0.11 & 3.97 & 1.74 & 0.01 & 0.73 & 0.85 & 7.49 \\
\hline Late & 186 & 0.01 & 0.01 & 4.74 & 1.52 & 0.01 & 0.71 & 2.66 & 9.66 \\
\hline Stored nontreated & $(21)$ & 0.07 & 0.10 & 3.06 & 1.49 & 0.01 & 0.84 & 1.01 & 6.58 \\
\hline Nonstored nontreated & 193 & 0.09 & 0.13 & 3.67 & 1.58 & 0.01 & 0.98 & 2.67 & 9.13 \\
\hline Early & 193 & 0.06 & 0.10 & 1.86 & 1.16 & 0.01 & 0.66 & 0.50 & 4.35 \\
\hline Mid & 193 & 0.15 & 0.17 & 2.98 & 2.32 & 0.01 & 0.84 & 0.52 & 6.99 \\
\hline Late & 193 & 0.08 & 0.10 & 2.25 & 0.95 & 0.04 & 0.89 & 1.55 & 5.86 \\
\hline Stored nontreated & (28) & 0.09 & 0.16 & 2.44 & 1.69 & 0.02 & 0.73 & 0.28 & 5.41 \\
\hline Nonstored nontreated & 200 & 0.07 & 0.09 & 1.93 & 1.02 & 0.04 & 0.77 & 0.93 & 4.85 \\
\hline Mid & 200 & 0.09 & 0.07 & 1.46 & 1.03 & 0.04 & 0.51 & 0.53 & 3.73 \\
\hline Late & 200 & 0.07 & 0.12 & 1.60 & 1.32 & 0.04 & 0.62 & 0.28 & 4.05 \\
\hline Stored nontreated & $(35)$ & 0.07 & 0.10 & 1.76 & 1.22 & 0.03 & 0.53 & 0.15 & 3.86 \\
\hline Nonstored nontreated & 207 & 0.07 & 0.09 & 2.06 & 1.27 & 0.04 & 0.63 & 0.52 & 4.68 \\
\hline Late & 207 & 0.06 & 0.07 & 1.23 & 1.41 & 0.04 & 0.51 & 0.22 & 3.54 \\
\hline
\end{tabular}

${ }^{\mathrm{z}}$ See Table 1 for explanation of treatments.

y Data are the means (a standard error of each mean is $<6 \%$ ) of three replications.

${ }^{x}$ Value in parentheses is storage time (d) for stored nontreated fruit harvested 165 DAFB.

change throughout ripening. However, it is considered that the concentration of low-molecular-weight polyuronide in the fruit increased with ripening because the percentage of WSP in the total polyuronides increased. This conclusion is supported by the fact that total polyuronide concentrations decreased with time, indicating that polyuronide reduced to a lower molecular weight with time and might be not have been recovered as AIS.

Cell wall neutral sugars also decrease as fruit ripen (Ahmed and Labavitch, 1980; Huber, 1983). In this study, although xylose showed almost no change, glucose from cell walls decreased greatly with ripening, followed by arabinose. Hence, it can be assumed that starch was hydrolyzed to soluble sugars of low molecular weight with ripening and a loss of glucose in AIS occurred, resulting in fruit softening. Knee (1973) and Yoshioka et al. (1994) reported that neutral sugar concentration in apple is low in WSP fractions released during softening. In particular, arabinose and primarily galactose residues are lost from the cell walls. Thus, the detailed relationship between softening and neutral sugars merits investigation in each fraction divided into WSP, HMP, HP, hemicellulose, and cellulose.

Normally, skin color of 'La France' pears undergoes almost no change with maturity (Fig. 2). However, the skin color of 2,4-DPtreated fruit changed from green to yellow with ripening. This observation may be beneficial for studying the conditions of fruit ripening and determining optimum harvest date.

\section{Literature Cited}

Ahmed, A.E. and J.M. Labavitch. 1980. Cell wall metabolism in ripening fruit. I. Cell wall changes in ripening 'Bartlett' pears. Plant Physiol. 65:1009-1013. 
Albersheim, P., D.J. Nevins, P.D. English, and A. Karr. 1967. A method for the analysis of sugars in plant cell wall polysaccharides by GLC. Carbohydrate Res. 5:340-345.

Blankenship, S.M. and D.G. Richardson. 1985. Development of ethylene biosynthesis and ethylene-induced ripening in 'd'Anjou' pears during the cold requirement for ripening. J. Amer. Soc. Hort. Sci. 110:520-523.

Chen, P.M. and W.M. Mellenthin. 1981. Effects of harvest date on ripening capacity and postharvest life of 'd'Anjou' pears. J. Amer. Soc. Hort. Sci. 106:38-42.

Chen, P.M., W.M. Mellenthin, and D.M. Borgic. 1983. Changes in ripening behavior of 'd'Anjou' pears (Pyrus communis L.) after cold storage. Scientia Hort. 21:137-146.

Chen, P.M., D.M. Varga, and E.A. Mielke. 1993. Ripening behavior of 'Columbia' and 'Gebhard' strains of Red 'd'Anjou' pears after cold storage. J. Amer. Soc. Hort. Sci. 118:81-85.

Gerasopoulos, D. and D.G. Richardson. 1997. Storage-temperaturedependent time separation of softening and chlorophyll loss from the autocatalytic ethylene pathway and other ripening events of 'Anjou' pears. J. Amer. Soc. Hort. Sci. 122:680-685.

Huber, D.J. 1983. The role of cell wall hydrolases in fruit softening. Hort. Rev. 5:169-219.

Knee, M. 1973. Polysaccharide changes in cell walls of ripening apples. Phytochem. 12:1543-1549.

Knee, M. 1993. Pome fruits, p. 325-346. In: G. Seymour, J. Taylor, and G. Tucke (eds.). Biochemistry of fruit ripening. Chapman and Hall, London.

Kondo, S. and Y. Hayata. 1995. Effects of AVG and 2,4-DP on preharvest drop and fruit quality of 'Tsugaru' apples. J. Jpn. Soc. Hort. Sci. 64:275-281.

Kondo, S., J. Uthaibutra, and H. Gemma. 1991. Comparison of 1aminocyclopropane-1-carboxylic acid, abscisic acid and anthocyanin content of some apple cultivars during fruit growth and maturation. $\mathrm{J}$. Jpn. Soc. Hort. Sci. 60:505-511.

Manabe, T. 1993. Comparative examination of the three quantitative methods of pectin (carbazole, m-hydroxydiphenyl and 3,5dimethylphenol method). Hiroshima Pref. Univ. Bul. 5:141-150.

McGuire, R.G. 1992. Reporting of objective color measurements. HortScience 27:1254-1255.

Michel, F., J.F. Thibault, C. Mercier, F. Heitz, and F. Pouillaude. 1985. Extraction and characterization of pectins from sugar beet pulp. J. Food Sci. 50:1499-1500.

Murayama, H., T. Takahashi, R. Honda, and T. Fukushima. 1998. Cell wall changes in pear fruit softening on and off the tree. Postharvest Biol. Technol. 10:21-27.

Naohara, J. and M. Manabe. 1994. Molecular mass and solubility changes in pectins during storage of satsuma mandarin fruits (Citrus unshiu Marc.). J. Food Sci. 59:578-580.

Nii, N. 1998. Structure of flower organ and fruit formation, p. 23-53. In: N. Nii (ed.). Fruit growth and development. Asakura Press, Tokyo.

Satoh, K. 1996. Decision of harvest date, p. 25-29. In: Editorial committee of the system of agricultural technology (ed.). The system of agricultural technology of pear. Soc. Culture Agr. Village Press, Tokyo.

Wang, C.Y., W.M. Mellenthin, and E. Hansen. 1971. Effect of temperature on development of premature ripening in 'Bartlett' pears. J. Amer. Soc. Hort. Sci. 96:122-125.

Yoshioka, H., K. Aoba, and Y. Kashimura. 1992. Molecular weight and degree of methoxylation in cell wall polyuronide during softening in pear and apple fruit. J. Amer. Soc. Hort. Sci. 117:600-606.

Yoshioka, H., Y. Kashimura, and K. Kaneko. 1994. Solubilization and distribution of neutral sugar residues derived from polyuronides during the softening in apple fruit. J. Jpn. Soc. Hort. Sci. 63:173-182. 